\title{
AN ANALYSIS OF THE MILITARY REGIME IN EDO STATE: STRENGTH AND WEAKNESSES, 1991-1999
}

\author{
Michael EDIAGBONYA (Ph.D.)* \\ michaelediagbonya01@gmail.com \\ Department of History and International Studies, Ekiti State University, Ado-Ekiti, Nigeria
}

\begin{abstract}
This paper examines the Military Regime in Edo State. It discusses the military governors of the state between the period of 1991-1999. It analyses the strength and weaknesses of the military governors during the period under focus. Data for the study was obtained through oral interview as primary sources and secondary sources like books, newspapers, articles, journals, theses and dissertation were also used. It was found that some of the military governors contributed immensely to the development of Edo State. It was also found that Captain Baba Adamulyam, the governor between 1996-1998 was more of a curse than a blessing to the people of Edo State. It concludes that military rule is an aberration.
\end{abstract}

Published by IJRP.ORG. Selection and/or peer-review under responsibility of International Journal of Research Publications (IJRP.ORG)

Keywords: Military, Development, arbitrary decisions, strength, weaknesses.

\section{Introduction}

Military rule in Nigeria started in 1966 after the abortive coup of January 15, 1966. Some Majors in the Nigeria army led by Major Chukwuma Kaduna Nzeogwu organised this coup. Following the failure of the coup, the most senior officer in the army, Major General Aguiyi-Ironsi became the Head of State and Commander-in-Chief of the Armed Forces. Thus the first military administration in Nigeria was established and the military dominated the political scene in Nigeria from 1966-1979 and between 1983-1999.

Adeyemi argues that since the early hours of January 15, 1966 when some soldiers benefiting from the conspiracy of darkness, stealthily rose up in arms and assassinated AlhajiTafawaBalewa, S. L. Akintola, Ahmadu Bello and took power from Federal and Regional Civilian leaders, violence and instability have become the main event in the Nigerian political arena (Adeyemi, 1999). The coup marked a landmark political misadventure which marked the beginning of military coups in Nigeria.

Again in Nigeria in 1985, there was another military coup. The military administration of General MuhammaduBuhari which came in January 1984 was overthrown by the Ibrahim BadamosiBabangida Junta in a palace coup on August 27, 1985. This administration of General Buhari only lasted for a year and eight months (December 31, 1983-August 27, 1985).

Inspite of the shortcoming of General Babanigida's administration, one area in which the Government needs commendation was in the area of the creation of states. Babangida's administration in 1987 created two states, Akwalbom and Katsina. In 1991, nine more states were created.

\section{Creation of Edo State}

Edo state was created on August 27, 1991 as one of the nine new states created by the former President, General Ibrahim Babangida (The Nigeria Observer, October, 2010). The state was exercised from the former Bendel State in the landmark event that changed the political structure of the country from 21 to 30 States (Ediagbonya, 2007:61). The desire for the creation of Edo State commenced on Thursday July 16, 1981, when Oba Erediauwa, the great Benin Monarch led a powerful delegation of eminent indigenes to the National Assembly in Lagos to formally present the request. Although this request was not immediately granted. Interestingly it formed the basis for the priority accorded state creation ten years later by General Ibrahim Babangida military administration (Ediagbonya, 2017). 
Edo State is made up of 18 Local Government areas. It is divided into three senatorial districts which include Edo South, Edo Central and Edo North. Edo State was ruled by the military between 1991 and 1999. The first military governor in Edo State was Col. John EwevekumohYeri (1991-1992). He did a lot for the people of Edo State. Others who came after him like Mohammed AbdulsalamOnuka (1993-1994), Col. BasseyAsuquo (19941996), Group Captain Baba AdamuIyam (1996-1998) and Navy Captain Al. OnyearugbuLem (1998-1999) contributed greatly to the development of the state (Ibid, xi).

Inspite of the above contributions of the military administration in Edo State, Section 197 of the 1979 Constitution of the Federation States the functions of military thus:

(a) Defending Nigeria from external aggression

(b) Maintaining its territorial integrity and securing its borders from violation on Land, Sea or Air.

(c) Suppressing insurrection and acting in aid of civil authorities to restore order when called upon to do so (Constitution of the Federal Republic of Nigeria 1979: Section 197).

It is important to state here generally that the military has never succeeded in political governance because they are authoritarian and insensitive to the general will of the people. Inspite of the achievements of the military governors in Edo State, the state between the periods of 1991-1999 witnessed bureaucratic violation, taking arbitrary decisions without recourse to bureaucratic channels.

\section{The Strength and Weaknesses of Military Rule in Edo State}

\subsection{Col. John EwerekumohYeri, August 27, 1991-1992} Strength

Col. John EwerekumohYeri was the former Governor of the Defunct Bendel State. He took over from Brigadier Jonathan TundeOgbeha on July 31, 1990. Following the creation of Edo and Delta States from Bendal State by General Ibrahim Babangida on August 27, 1991, Col. Yeri became the Governor of the State. On August 30, 1991, Col. Yeri charged the people to co-operate in its efforts to lay a solid foundation for its subsequent development (Yeri's Broadcast, August 30, 1991).

The first major achievement of the military Governor was ensuring equitable distribution of assets of the defunct Bendel State. The Governor expressed optimism that the assets of the defunct Bendel State would be shared equitably. As he puts it:

"This administration trusts the understanding of the Federal Government and I know that it would certainly ensure that Edo State will benefit equitably from the sharing of the asserts of the defunct Bendel State (The Nigerian Observer, 1991:16)".

He pursued this asset sharing with dogged determination and to its logical conclusion. The patriotism dislayed by the Governor regarding this assert sharing was highly admired by the people of the state. The second challenge which the Governor faced was the movement of civil servants from the two states. As a concerned Governor, he quickly observed that owing to the movement of persons to Delta State, the machinery of the administration in some key public institutions in the state was adversely affected, hence the reconstitution of the Civil Service Commission at the Post Primary School Board. As part of the movement, Edo State Government under Yeri, directed the Civil Servants who are indigenes of the newly created Delta State to go to their state. The Secretary to the State Government, Abdul Umoru directed the Ministries and Departments to ensure that the last pay certificate for officers affected by the movement should be prepared and handed over to them so as to facilitate action on the payment of officers' salaries on arrivals at Asaba (Ibid).

Governor Yeri needs to be commended for being able to ensure equitable sharing of assets and also ensuring the movement of civil servants from both states. This assignment needs adequate planning, patience, consultation, enough funding, proper management, tolerance to succeed, that he succeeded shows his qualities of statesmanship. 
On the future development of Edo State, the Governor established an Economic Advisory Council. The Council was made up of prominent Edo Sons and daughters drawn from all Sections of the State. According to the Governor, the council would be entrusted with the responsibility of advising the government on measures to ensure a viable and sustainable development (Ibid).

In order to put the state capital, Benin City, on a sound footing, $\$ 100$ Million Benin City Development Fund was launched on December 7, 1991. Governor Yeri donated N5.Million on behalf of the State Government while the Federal Government donated N1Million (Sunday observer, December 8, 1991).

This huge amount went a long way in putting many things right in the state capital and beyond. In the pursuance of peace in Edo State, the Governor, on Thursday November 6, 1991, summoned a meeting of religious leaders and traditional rulers to appeal for peace and harmony. It was a campaign for peaceful co-existence, this meeting became necessary to douse the flame of possible religious fracas in the state. The meeting was particularly paramount in view of the unfortunate events in Kano where a number of our people amongst other Nigerians either suffered loss of their lives or their properties.

One would agree with me that in an atmosphere of rancour, animosity, acrimony, pandemonium, unmitigated disaster, no development can take place. Hence, the pursuance of peace at this period is highly commendable.

Governor Yeri was not alone in the governance of the state. He saw the need to bring in Commissioners to assist him in the affairs of the state. It is on record that he appointed technocrats and professionals of high repute and integrity as commissioners. Those appointed as Commissioners include:

1. Dr. Michael ArigbeOsula-Commissioner for Finance, Commerce and Industry.

2. Prof. Joseph Agbhenta-Commissioner for Education, Sports and Culture.

3. Dr. Stephen Irune-Commissioner for Health, Social Development and Youths etc.

These Commissioners assisted him in the day to day running of Government. In the area of education, Col. Yeri also left a mark. The government approved the appointment of 1, 110 teachers and 160 non-teaching staff. The State Post Primary Education Board was given instruction to carry out this assignment. It is a known fact that any educational system without trained and adequate number of teachers is a wasted investment. In order to boost the moral of teachers and motivate them for better productivity, Governor Yeri promoted 6, 026 teaching and nonteaching staff. He also release the sum of $\$ 756,766$ to meet the additional personnel cost arising from the promotion exercise (Ediagbonya, 2007: 69).

Governor Yeri deserves a high level of commendation against the backdrop that education is the greatest legacy which can be bequeathed to children. Governor Yeri also ensured the successful conduct of the 1991 Census in Edo State. The significance of census to a state cannot be over-emphasized. It determines the numerical strength of a state in the federal legislature. More importantly, it determines the allocation which each state or region collects from the federation account or from the Central distributable pool. So for a government to be able to organise an acceptable head court in the state is a very serious achievement.

In order to ensure strict compliance, the Governor declared two days a as public holiday (November 28 and $29,1991)$ to enable civil servants to participate fully. He also re-affirmed the restriction of movement of persons for two consecutive days beginning from Wednesday November 27, 1991. He assigned public officers of the rank of Directors and above to monitor the conduct of the 1991 census exercise. At the end of the exercise, it was very successful and acceptable. Thus the census result which placed the state above 2 million, formed the basis for adequate planning in the state and also determines what the state earned from the federation account between 1991 and 2003 when another census was conducted.

Another area where Governor Yeri attracted commendation was in the area of smooth transitions to civil rule in the state. One would recall that President Ibrahim Babangida approved the formation of two political parties, which were social Democratic Party and National Republic Convention on $7^{\text {th }}$ October, 1989. With this formation, the regime's transition programme was on course. The first step the Governor took was the administration of the oath of office for interim administration for councils. In keeping with Decree 15 of 1989 which made provision for interim administration, the Governor of Edo State, Col. Yeri administered oath of office to the sole administrators of the twelve councils including six new ones. (Decree 15 of 1989). The interim administration inaugurated under the 
provisions of Section 34 of the Local Government (Basic Constitutional and Transition Provisions) Decree 15 of 1989 were to run the dissolve councils before the National Electoral Commission (NEC) conducts elections to fill chairmanship and councillorship seats there (Decree 15, 1989, Section 34).

When the election came up on Saturday, $23^{\text {rd }}$ November 1991, the Governor of the State, Col. Yeri directed Commissioners and Directors-General to monitor the conduct of the election. He instructed them to submit a comprehensive report on the conduct of the elections in their areas of assignment to the Secretary to the State Government not later than Monday, 25 November, 1991 (Ediagbonya, 2007).

At the end of the day, the election was very successful in the state thus ushered in a democratically elected councilors and chairmen into various councils in the state. In the same spirit, he also ensured the success of the election into the State House of Assembly and Governorship Election which produced the first elected Governor of Edo State, in the person of Chief John OdigieOyegun; who came in under the platform of Social Democratic Party (SDP) in 1992.

Infact, no achievement can be more than this, as the people now have government of their own, since democracy is the government of the people by the people and for the people. Governor Yeri embarked on vigorous and aggressive road constructions in the state capital. He built culverts along the notorious Iyobosa Street in Benin City. The Governor also directed his attention to the provision of social amenities. For example he formally commissioned the $\$ 23$ Million water Bolehole Project in Ovia North-East Local Government Area at Uhen. There was also $\$ 450$ Million Benin City water supply scheme and the $\$ 120$ Million Northern Ishan Water Scheme (The Nigerian Observer, November 14, 1991).

A constructive assessment of the above achievements of Col Yeri shows a bold step towards developing the new state. However there were weaknesses of this administration.

\section{Weaknesses}

The first demerit of this administration was bureaucratic violation, taking arbitrary decisions without recourse to bureaucratic channels. It was a period where the citizens of Edo State were subjected to coercive discipline administered with calculated military precision. Another serious weakness of this administration was delay in payment of workers' salaries. Under Col. Yeri's administration, it went to the extent that public servants threatened not to participate in the census exercise in the state if their salary was not paid.

\subsection{LT. COLONEL MOHAMMED ABDUSALEM ONUKA, 1993-1994} Strength

Following the dissolution of the Interim National Government led by Chief Earnest Shonekan, General SaniAbacha became the Head of State of Nigeria. In same vein, Lt. Col. Onuka was appointed the Military Administrator of Edo State. To ensure the effective running of his administration in the state, he appointed the following Commissioners.

(a) Mr. IrediaOsifo-Commissioner for Justice

(b) Engr. Gabriel AgbonaehorOnobun-Commissioner for works and Transports.

(c) Mr. George AnefomehUwaya-Commissioner for Education

(d) Mr. Petacelessy Isi Oribabhor Commissioner for Social development and Youths.

(e) Dr. Benjamin EghobahonOkpere-Commissioner for Health

(f) Mr. Rufus Stephen Aizeboje- Commissioner for Finance

(g) Mr. Emmanuel Dele Balogun-Commissioner for Commerce and Industry

(h) Mrs. Winifred, Onyeonwu- Commissioner for Local Government.

(i) Dr. Napoleon OsaruyiAiseni- Commissioner for Agriculture.

The new Commissioners were sworn in by the Military Administrator on February 17, 1994 (Ediagbonya, 2007: 78).

The first major problem which GovOnukatackled, was the issue of graduated salary deductions of public servants. This measure which was adopted by defunct John Odigie-Oyegun regime to reduce the financial predicament which the state was passing through was not palatable to the workers. Infact, it was having adverse 
effects on the productivity of the workers (Interview with Hon Igunbor, 2018). Gov. Onuka terminated the graduated salary deductions imposed on workers. The Secretary to the State Government Mr. OluGaruba, directed all arms of the public service to restore the full pay for workers with effect from February 1, 1994. (An Interview with Barrister Charles Aiyamenkhue, 2019). The workers celebrated this achievement as they poured encomiums on Gov. Onuka which they called God sent. In a way, the Governor boosted the morale of workers which enhanced effectiveness and efficiency. The productivity of workers became high in line with the popular saying that "To whom much is given, much is expected". In juxtaposition of that Gov. Onuka ensured regular payment of salaries and he often pay unscheduled visit to some ministries in the state capital to assess the extent of the success of the payment of workers' salaries.

In order to re-awaken the sanitation consciousness of the people of Edo State, Gov. Onuka constituted the Environmental Sanitation Task Force, led by Major Augustine Mainga. Also for the purpose of effective disposal of waste materials, the Governor suggested that the dumping site at Etete be pushed further inside (An Interview with Madam IfuekoEghaghe, 2017). In the same vein, one hundred and forty persons were arrested on February, 1994 by the State Environmental, Task Force for failing to observe the monthly sanitation exercise. They were charged in accordance with the stipulations of 1986 environmental sanitation edict, depending on the gravity of the offence (Edo State Environmental Sanitation Edict, 1986). This helped to ensure strict compliance by the people. Infact there is nothing as good as a healthy and clean environment.

Another area where the Governor focused attention was the negative activities of the 'Agberos' in the various parks in the state. These "agberos" during this period constituted social and nuisance value in the state. Infact "Agberos" refer to as touts are found in motor parks and their environs collecting illegal levies from drivers and using every coercive measure to oppress them. These illegal levies imposed on drivers led to increase transport fares generally. They sometime molest, intimidate, harsh and beat innocent passengers who were in the habit of taken transport along the road instead of parks (Interview with Bernard Raji, 2020). They have no government approval to operate. As a result of their notorious activities the parks became hot spots as innocent persons were often beaten or humiliated by them. The Governor was not happy with this illegality and hooliganism, so the administration outlawed "Agberos" and set up mobile courts to try convicts.

According to FautinesOvienrioba:

"Barely one month after the Edo State Government revoked the certificate of occupancy of the National Union of Road Transport Workers (NURTW), in addition to banning their activities at the parks, transportation fare in the state reduced considerably by almost 50\% (The Nigerian Observer, February 2, 1994). It was observed that before the ban on the activities of the agberos in the parks, the transportation fare from Benin to Asaba was between $\$ 50$ and $\$ 100$ per passenger. Now it is between $\$ 50$ and $\$ 60$. Benin to Onitsha was reduced to $\$ 80$ against the initial cost of $\$ 150$ while the cost of travelling from Benin to Agbor reduced to an appreciable level of $\$ 40$ from $\$ 80$. This was an area that benefited the generally of the public.

Governor constructed many roads in the state. The Governor met its part of the obligations to contractors. For example the administration directed the Niger Cat Construction Company Limited, handling the Upper Mission road and Ikpoba bridge project to resume work immediately noting that the government has met its part of the obligation to the company. The Governor who spoke through the Commissioner of Works, Mr. Gabriel Onobuh, on February 28, 1994 while on continuation of the inspection tour of office and projects under his Ministry warned other contractors handling road projects said that, the government will not hesitate to terminate any contract where the contractor fails to deliver according to specification (Ediagbonya, 2007: 80). This in actual fact shows commitment devotion and desire to work.

In order to facilitate efficiency and effectiveness on the part of teachers, Gov. Onuka approved subventions to public secondary schools in order to ensure the day-to-day running of the school system. Also with the revocation of the $20 \%$ compulsory monthly savings imposed on workers by the Oyegun administration, teachers now get their full pay again and this gesture on part of Onuka motivated the teachers for greater productivity. The pains which the graduated salary deductions imposed on the teachers cannot be over-emphasized. The teachers saw this revocation of the $20 \%$ compulsory monthly savings as the greatest achievement of this regime.

\section{Weaknesses}


However, inspite of the achievements of Gov. Onuka, he failed the people in many areas. First was the problem of delay in the payment of workers salaries and allowances. Workers were in difficulty because their salaries could not be paid as when due. A critical study of the situation on ground was that the government can adequately pay salaries at the end of each month, but the real problem was the issue of financial misconduct. There is enough evidence now to show that military rule was very corrupt. At the expiration of SanniAbacha's regime, it was discovered that, he looted the national treasury to the tune of 600 Billion US Dollars. Also General Babangida a former President of Nigeria was acclaimed as one of the richest persons in the world.

Again Gov. Onuka took arbitrary decisions without recourse to bureaucratic channels. The unilateral decisions which he took affected the morale of civil servants and sometimes resulted to civil unrest (Adeyemi, 1999). The most disgraceful aspect of GovOnuka's administration was when he gambled with the slim finances of the state. Many felt disappointed that a Governor could be involved in gambling. The Governor used part of the money which was loan facility secured by the Government for the Benin City massive water works. An observer's correspondent Monday Uwagwu noted that Edo State Government may be heading for more economic woes, following its ability so far to recoup more than $\$ 100$ million, from the vault of an ailing bank (Nigeria Observer, February 10, 1994). Simply put 'the money was trapped'. That money was lodged in the bank by agents of the government apparently to earn more money by way of interest for the state.

\subsection{Col. BasseyAsuquo 1994-1996}

Col. BasseyAsuquo, now Brigadier was the military Governor of Edo State between 1994 and 1996. The first assignment he did was to tour the 14 Local Government Areas to have a spot assessment of situations. Based on this spot assessment, he now put in structures to address the different problems. In order to ensure the day to day running of administration in the state, men and women of high integrity and credibility were appointed as commissioner. Those appointed as commissioners included the following:

a. Dr. M. I. Isokun- Hon Commissioner for Education.

b. Mrs. Winifred OsaruOnyeonwu- Hon. Commissioner for Information, Social Development, Youth and Culture.

c. Dr. Benjamin Okpere- Hon. Commissioner for Health

d. Engr. Austin Erhabor Hon. Commissioner for Public Utilities and Rural Development

e. Mr. George Uwaya- Hon. Commissioner for Special Duties

f. Mr. Steve O. Odigie- Hon. Commissioner for Justice and Attorney General.

Mr. OluGaruba was appointed as Secretary to the State Government. On the strength of that, the stage was not set for proper administration of the state.

Realizing the dwindling internally generated revenue of the state, Gov. Asuquo inaugurated a Task Force on Internal Revenue Generation in Edo State. The terms of reference to the Task Force were geared towards boosting the internally generated revenue of the state. On expenditure, area of waste in government spending was considerably reduced with capital expenditure now geared towards stimulating the productive sector of the economy (Ediagbonya, 2007).

According to Adeyemi, Brigadier General BasseyAsuquo settled all outstanding salary arrears and restored the leave transport grant to workers (Adeyemi, 1999: 10-20). The Governor also restored the annual incremental benefits to civil servants. This, no doubt boosted the morale of workers for better productivity. Confirming this, Governor Asuquo, in his address on the eve of the New Year said, the monthly salary bill of public officers now stands at well over $\$ 61$ Million per month (Governor Asuquo, An Address delivered on 31 ${ }^{\text {st }}$ December, 1994). He added that salaries are now paid as at when due as a result of government prudent spending coupled with the fact that the embargo on payment of full salaries/allowance and promotion of officers in the public service was lifted (Ibid). It was also said that the sum of $\$ 118$ Million had been disbursed for the payment of pensions and gratuities to retired public officers (The Observer, January 2, 1995). This no doubt is highly appreciated considering the predicament and hazards, the retired public officers suffer from most government of pensions and gratuities.

In the area of industrial development, Gov. Asuquo took some bold steps. In the first place, the privatized Bendel Brewery was refurbished and re-commissioned. This helped to improve the quality of its products, e.g. 
Crystal Classique Lager Beer and Crystal Malt. Gov. Asuquo also provided social amenities to the people. In his address at the eve of the New Year, he maintained that:

"In recognition of the fact that no government that is worth its salt can trifle with the welfare of its citizens, measures are being put in place to provide social amenities (Ibid).

True to his words, the Government of Edo State signed agreement with the World Bank for the Sum of \$155,232,000.00 under the National Water Rehabilitation Scheme for the provision of portable water in three locations of Ojirami, Ewohimi and Auchi/Jaffu. The Benin City Water Project was also progressing. In the area of Sports, Gov. Asuquo provides a conducive environment for the state to maintain its Leadership position in the country. The first step the Government took was to organize the launching of the Edo State Sports Development Appeal Fund which took place on Saturday July 20, 1996. Before this, Col. BasseyAsuquo constituted and inaugurated the Edo State Sports Development Appeal Fund Committee on June 9, 1995. The Appeal Fund Committee was headed by (Rtd) Col. P. O. Ogbebor who did a good job and the launching was very successful (Edo State Handbook, 1996: 5-11). It attracted dignitaries from within and outside the country. These included Lt. Gen. JT Useni, Hon. Minister, Federal Capital Territory, who was the Chairman of the occasion and Lt. General OladipoDiya, Chief of General Staff who was the Special Guest of Honour (Ibid). The money realized helped to provide modern buildings and equipment or facilities for the stadium in line with Olympics Standard (Ibid).

Also, Edo State as a foremost state in Sports continue to enjoy a leading place in sport development in the country through the active support of the State Government. This support manifested in the adequate provision made for the state's participation in the $10^{\text {th }}$ National Sports Festival held in Makurdi, Benue State, in April, 1996. Edo State emerged second in the competition by winning 28 Gold, 25 Silver and 29 Bronze Medals (Ediagbonya, 2007: 86). As a result of this victory, Governor Asuquo gave cash awards and promotions to the victorious athletes in various sports. The sums which ranged between $\$ 2,000$ and $\$ 10,000$ were given to such sportsmen and women as well as coaches.

In the area of football, during the regime of Gov. Asuquo, the Insurance Football Club of Benin won two continental Football Cups for the Country in 1994, the West African Football Union (WAFU) and the Confederation of Africa Football Cup (CAF). The State Government announced a package of incentives to the players and officials of the club. It was said that in appreciation of this double victory, the Head of State, General SaniAbacha donated \#2Million to the Club during his November, 1995 visit to Edo State (Edo State Handbook, 1996:23).

In the area of Agriculture, Gov. Asuquo took some steps, in order to bring about agricultural revolution. In a report presented by Leo Atapka, an observer correspondent said, Dr. Aisueni, the Commissioner for Agriculture announced that the State Government approved the sum of $\$ 510,000$ as counterpart funding of the ECOWAS fund fishing Loan Project of its share assistance to the artisanal fishing industry (The Nigerian Observer, January 25, 1995).

Also, Agricultural Development Programme (ADP) opened a fertilizer store in the premises of the headquarters at Oko, Benin City to ease the sales of the commodity to farmers who want less than five bags at a time. These measures no doubt, helped to encourage farmers' interest in farming, as productivity increased generally.

During the same period, the regime of Gov. Asuquo approved $\$ 2.5$ Million for the provision of basic facilities at the state College of Agriculture, Iguoriakhi, Ovia Southwest Local Government to enable it meet the demands of National Board for Technical Education (NBTE) for the effective take off of the institution. Considering the above achievements of Gov. Asuquo, it may be wrong to say that military regime though illegal did not contribute to the development of Edo State. 


\section{Weaknesses}

However Gov. Asuquo failed in the following areas. First, Col. BasseyAsuquo started the calamity of retrenchment in the state. The government reduced the workforce in the state by $20 \%$. Those affected went through much predicament as the Government did not make provisions to settle them for a profitable life.

Adeyemi maintained that the Governor sometimes jettisoned what was considered as bureaucratic bottle necks and opted for military fiat without thinking of the rippling effects of such arbitrary actions and the socioeconomic aspiration of the state (Adeyemi, 1999).

During this time, as a result of non-payment of salaries and allowances, there was civil unrest in the state:

Adeyemi noted that:

This ugly situation precipitated industrial unrests, lockouts and strikes by aggrieved civil servants in the Ministries and Government parastatals (Ibid).

Col BasseyAsuquo was also discredited for introducing 'staggered salary payment system in the state. Under the system, workers in the ministries, teaching service and parastatals were to receive salaries at different times in a month. It was possible for a parastatal to receive salary at the first week of the month, while the other ministry could receive their salary at the end of the same month (An Interview with OsagieEdobor, 2018).

Thus, arrears continued to increase while workers continued to experience untold hardship. Infact they were in bondage. Under such a nasty atmosphere, much was not expected from workers, as their morale was brought down which had adverse effects on their productivity.

\subsection{Group Captain Baba AdamuIyam (August 26, 1996-August 1998) Strength}

Following the hire and cry over the administrative incompetence of most state military administrators, General SaniAbacha was compelled to deploy some military administrators to the barracks while others swopped positions with their counterparts in other states. This swopping of Military Governors brought Group Captain Baba AdamuIyam to Edo State. The Governor arrived Benin City on August 26, 1996 to assume duty as Military Administrator.

Unlike other military Governors of Edo State, he preferred to work with Directors-General instead of Commissioners to ensure the day to day running of administration. The following Director-General were appointed:

a. Dr. S. A. A. Okpaise- Ministry of Health.

b. Mrs. T. Akomolafe Wilson-Ministry of Justice

c. Mr. S. I. Ekhator- Local Government and Chieftaincy Affairs.

d. Mr. K. C. Idemudia- Ministry of Education.

e. Mrs. A. O. Garuba- Ministry of Works and Transport

f. Dr. F. A. Ekhaguere- Ministry of Agriculture and Natural Resources.

g. Mr. C. Okosun-Unified Teaching Service

h. Mr. P. K. Ebuekhi- Ministry of Finance

i. Mr. U. U. Ikhide- Administration, Cabinet and Political Matters

j. Engr. J. I. Isidahomen- Lands and Survey

k. Mr. M. A. Aiwujo- Budget, Planning, Statistics and Special Services.

1. Mr. A. A. Ekhayeme- Ministry of Commerce and Industry

m. Alhaji Y. Garuba- Establishments, Pensions and Gratuities

n. Mr. D. E. Inneh-Ministry of Information, Youth and Culture.

Alhaji D. E. Musah was appointed the Acting Secretary to the State Government.

First, he was not happy with the fuel situation in the state. So he set up the Petroleum Task Force. For a start, the task closed down nine filling stations in Benin City for hoarding and diversion of the commodity. According to a report presented by Roland Osakhue an observer correspondent, the filling stations sealed for hoarding were NochealRetrol station, National, Sapele Road, Total, M. M. Way National, M. M. way and Total 
Akpakpava. Those sealed for diversion included AP, Sapele Road, Mousco, Sapele Road, Alex O, Sapele Road and Mobil Agbado, all in Benin City (The Nigerian Observer, January 25, 1995).

In the area of education, in July 1997, textbooks worth $\$ 30,075,000$ were distributed to 130 Secondary Schools under the first phase of the exercise. Another sum of $\$ 40,025,000$ was also approved for a similar venture to benefit schools under the second phase. During the period, approval was given for the establishment of 50 Private Secondary, 76 Primary and 65 Nursery Schools, while 35 Junior and 10 Senior Secondary Schools were granted recognition to write the Junior and Senior Secondary School Certificate Examinations (Edo State Handbook, 1997: $15)$.

Also, the Government paid out $\$ 4,719,902$ for contracts executed at the Mixed Model Secondary School, Fugar. The Government released the sum of $\$ 3,624,050.36$ for the completion of the Faculty of Law Building at the Edo State University, Ekpoma (Ibid). There is no doubt that education sector was given a conducive atmosphere to thrive.

In the area of information, the Governor also recorded some achievements. In the desire to ensure a state wide radio and television coverage by EBS, government released $\$ 2.4$ Million for the refurbishment of its transmitters (The Nigerian Observer, March 9, 1997). Even when the Nigerian Television Authority was not a parastatal of the state Government, Group Captain Iyam’s administration assisted the agency with \$1Million for the refurbishment of some vital equipment to enhance its services to the state (Ibid).

Weaknesses

He was described by many as a wild and the worse Governor in the state. While the People of Edo State were speculating on the kind of Governor they were expecting, most people in Kwara State were celebrating and jubilating over the exit of Iyam from their state.

It was a sad experience that, the Edo people were contending with the inglorious administration of Iyam and also, sharing from the tyrannical regime of the late dictator, SaniAbacha. In the first place, education which was the greatest industry in the State was completely in ruins. The Standard of education in Edo State became so low as a result of the increased school fees for secondary schools, retrenchment of teachers and delay in the payment of salaries to the few ones left in service. It was said that at his exit and the inception of the new administration of Navy Captain Onyearugbulem, education was in a bad state (Edo State Handbook, 1999: 13).

The school population had depleted to less than two third because the immediate past administration of Adam Iyam has increased school fees from two hundred naira to eight hundred and fifty naira. This led to the exodus of those who could not pay the exorbitant fees. Again those pupils that chose to stay had no teachers because the administration of Group Captailyam retrenched about 4,000 teachers (Ibid).

Also as a result of the self-sustaining policy introduced by this administration, no subventions were given to Edo State University, Ekpoma and College of Education, Ekiadolor. So, the College of Education, Ekiadolor could not pay salaries to its workers for about eight months. The college increased the school fees to $\$ 6,000$ from N3,000 per session in order to survive. It was the salvage mission of Navy Captain Anthon Onyearugbulem that rescued these institutions from total collapse.

Adeyemi notes that Adamulyam started by ordering the immediate retrenchment of all workers employed in 1991 and thereafter resulting in the retrenchment of about 8,000 workers (Adeyemi, 1999).

His obnoxious self-sustaining policy also affected Edo Broadcasting Service, the Observer Newspapers, Library, Arts Council negatively. These institutions could not pay salaries to their workers for more than 10 months. Also Iyam dissolved the Executive Council which he inherited from Col. Asuquo and administered the state for more than a year without civil commissioners with whom he could deliberate on state matters.

This was really a non-chalant Governor, a dictator, a tyrant and a despot of a very high magnitude. Even with the mass retrenchment which he did he could not pay the few workers their salaries and allowances as when due. For many months, the workers lived on hopes and aspirations which could not be translated into practical reality. It was a very bad situation and bitter experience for workers in the state. Those things that made the Edo proud had been left to go into ruins. Edo State is regarded as the cradle of civilization in Nigeria because of its rich culture, dating back to centuries and the state had earned the reputation of being number one in sports, right from the first National Sports Festival in 1973. These two vital areas were completely neglected by Adamulyam. 
Little wonder, the people of this state were collective in prayer about the exit of this dictator. It was the biggest celebration and jubilation in the state when the news of his transfer came to the ears of Edo people who had been under pressure and tension as a result of his misrule.

\subsection{Navy Captain Anthony IbeOnyearugbulem August 12, 1998-May 29, 1999}

When General AbubakarAbdusalem took over as the Head of State of Nigeria, there was a major cabinet reshuffle. From this cabinet reshuffle Anthony Oniyearugbulem move from Ondo State to Edo State. Captain Onyearugbulem had come at a time when the condition of the state was becoming worse in the hands of Iyam.

The Governor quickly observed this when he assumed power. He declared: "One would want to recall that of recent, this area is now labeled the heartbeat of the nation. I am not unaware that also something had gone wrong with the heartbeat; perhaps, that slowed it down to some extent". All things are not normal and it does appear that the ship of state is still not floating on an even keel (Edo State Handbook, 1991:1).

The Governor concluded that there was the need for a "salvaged operation". On assumption of office, he said to the people that he was on a salvage mission to rescue Edo from social and economic predicament (The Nigerian Observer, March 26, 1998). He started by taking decisive steps to correct the ills perpetrated by the Iyam administration.

He reconstituted the Executive Council by appointing Commissioners which his predecessor Group Captain Adamulyam did not do. The following persons were appointed as Commissioners:

a. Mrs. ToluDanjuma- Attorney General and Commissioner for Justice

b. Dr. Mike Ehizokhale- Commissioner of Health

c. Mr. Henry D. Tenebe- Commissioner for Women Affairs

d. Mr. Elijah Willie- Commissioner of Finance

e. Mrs. Helen Ebueku- Commissioner of Information, Youth, Sports and Culture

f. Mr. Charles Igbinedion- Commissioner of Education

g. Architect Paks Paul Agoni- Commissioner of Works and Transport

h. Dr. John TundeErimafa- Commissioner of Agriculture

i. Mr. Patrick Abbe- Commissioner of Commerce

AlhajiDauda E. Musah was the Secretary to the State Government while Dr. S. A. A. Okpaise was the Head of Service, Edo State (Ediagbonya, 2007: 98).

The first to receive urgent attention was education, which was in a bad state. He re-opened shut schools and reduced the school fees payable in secondary schools, from $\mathrm{N} 850-\mathrm{N} 350$. The people of the state commended him so well in this reduction. The sum of $\mathrm{N} 60$ Million was used for the rehabilitation or renovation of 38 public secondary schools in the state. Also, 33 public primary schools were rehabilitated with $\$ 45$ Million (Edo State Handbook, 1991:1). Captain Onyearugbulem directed that 700 teachers who were affected by the retrenchment exercise be reabsorbed to boost the teaching of science in the schools.

In response to appeals by individuals and the students, he resumed subventions to the Edo State University, Ekpoma and the College of Education, Ekiadolor. He also reduced the school fees payable by the students of the College of Education, Ekiadolor from $\$ 6,000$ to $\$ 3,000$ per session. With the resumption of subvention to these institutions, they are now able to maintain their infrastructure and pay other bills as and when due. It would be recalled that the self-sustenance policy of the Adamulyam's administration affected these institutions which compelled these schools to increase their school fees by $100 \%$ and there was mass with drawal by those who could not pay.

In the 1999, Senior School Certificate Examinations, the Government paid $\$ 22,790,000$ representing $50 \%$ of WAEC fees for all final year students in both the public and private senior secondary schools. He was really a very wonderful Governor. This was what an elected Governor could not do. The Government released $\$ 11$ Million 
for the payment of arrears of eight months salaries owed the workers of the College of Education as a result of the self-sustenance policy of Group Captain Adamulyam.

In the area of agricultural sector, the government purchased 305 units of irrigation pumps, one project vehicle, installed 200 tube wells, 60 wash balls and constructed $1 \mathrm{~km}$ Fadama Road and another 3 Kilometres access road to facilitate dry-season farming (Ibid). The administration acquired ten new tractors with five trailers, five slashers, five harrows, as well as five reapers and five rice planters as efforts geared towards agricultural revolution in the state (Ibid).

In attempt to boost industrial development in the state, special attention was given to Bendel Cement Company Limited, Okepella the Governor released $\$ 60$ Million for the execution of refurbishment and reactivation plan of Bendel Cement Company, Okpella. To encourage the workers the administration approved \$30Million for disbursement to pensioners who have earlier been paid their gratuities (The Nigerian Observer, September 10, 1998).

In order to promote information network in the state, the Administrator directed his attention to Bendel Newspapers Company Ltd, Edo State, Edo Broadcasting Service. The Governor granted \$3Million life line for Bendel Newspaper Company Limited (BNCL) publishers of the Observer Group of Newspapers. With this assistance, the company would pull itself together and operate effectively and efficiently as a business outfit (The Nigerian Observer, October 2, 1998:2).

The Governor also rehabilitated the failed portions of most urban roads in Benin City. The State Government awarded the contract to the Nigerian Dynamics Limited at a total cost of \$7Million, five hundred and fifty-seven thousand and two Naira (Edo State Handbook, 1999: 53). Some of the repaired portions included:

1. Mission/New Lagos Road Junction, by New Benin Market.

2. Mission/Dawson Road Junction.

3. Ramat Park Area

4. ICE Road etc (Ibid)

This, no doubt promoted trading activities in the city and it also eased the movement of persons and goods in the state.

Lastly, the Military Administrator addressed the problem of water supply in the state. He released money to Urban Water Board to purchase submersible pumps for boreholes reactivation in Benin City. Under this administration, six new boreholes were drilled in Adesuwa Grammar School, Uwelu, Uokha, Iyakpi, Iguosa, Ohordua in order to improve the supply of potable water to the people of Edo State.

Governor Anthony IbeOnyearugbulem remained one of the best Governors to have ruled this state whether civilian or military.

\section{Weaknesses}

Although Navy Captain Anthony Onyearugbulem declared to the people of Edo State at the inception of his regime that he was on a salvage mission, there were areas where the Governor failed the people.

In the first case, he sometimes relied on military precision or fiat instead of appreciating constitutional means to issues. This brought about arbitrary actions to achieve unconstitutional decisions without considering their effects on the people.

Second, he was owing workers in some Ministries many months salaries and allowances. For example workers in Edo State Library Board were not paid 23 months salaries. Also workers of Nigeria Observer were in a very difficult situation because the Governor could not paid them their salaries for 18 months, while those in Edo Council for Arts and Culture were equally in pains because of the same problem of non-payment of their salaries for many months. This is an irony to observe that a Governor purported to be on salvage mission could be so insensitive to the plight of the people.

Of all his weaknesses, the one that was most embarrassing, disgraceful and humiliating was his acute partisan outlook. His support for People Democratic Party (PDP) became so open that the issue was a public discourse and a household discussion. It created tension, suspicion, bad blood in the political class. The other political parties like AD, APP were ready for a show down Governor Onyearugbulem was totally committed to the success of the PDP, Governorship candidate Chief Nosalgbinedion. 
It was revealed that Captain Onyearugbulem suspended the Oba of Benin as the Chairman of the Benin Traditional Council. This according to Tony Osazuwa was misinterpreted to mean the dethronement of the Oba by the Benin people (Interview with Osazuwa, $6^{\text {th }}$ May, 2007). There was much reaction by the people since their Oba was involved though the Governor denied that he was misunderstood, much water have passed under the bridge. The rift between Oba Erediauwa and the Governor generated from the information spreading among the PDP members in the state that the palace gave royal blessing to APP Governorship candidate Mr. Lucky Imasuen. Without investigating, the Governor started reacting and therefore caused unnecessary tension and acrimony in the peace loving state like Edo. He failed to realize that an insult to the Oba represents an insult to the totality of Benins. The Governor by his conduct showed that he lacked the knowledge of Ancient Benin Kingdom, where the Monarch was worshipped as a semi-god. May be, he was not also aware that the Oba of Benin attracts respect at both National and International Levels. Little wonder, he allowed himself to be used.

So, inspite of the laudable achievements of Captain Onyearugbulem his exit was inglorious because of his partisan outlook or posture.

\section{Conclusion}

Edo State was created on August 27, 1991 by the former Military President, General Ibrahim Babangida. The state was ruled by the military governors between 1991 and 1999. The first military governor was Col. John EwerekumohYeri (1991-1992). This was closely followed by Mohammed AbdulsalemOnuka (1993-1994). Others were: Col. BasseyAsuquo (1994-1996) Group Captain Baba Adamulyam (1996-1998) and Navy Captain A. I. Onyearugbulem (1998-1999). They all contributed to the development of Edo in different ways. The use of military fiat was common to all the military Governors.

However, it is established that Group Captain Baba Adamulyam was the worse Governor in the history of Edo State as education which was the greatest industry in the state was completely in ruins. Again the self-sustaining policy introduced by him affected Edo State University, Ekpoma, College of Education, Ekiadolor, Edo Broadcasting Service, the Observer Newspapers Library, Arts Council negatively. He ordered the retrenchment of about 8,000 workers.

Again, inspite of the partisan nature of Governor IbeOnyearugbulem, he remained the best military Governor of Edo State during the period under focus. 


\section{REFERENCES}

Adeyemi, A. M. The Impact of Military Rule on Public Administration: A Case Study of Edo Sc. Thesis, 1999.

A Hand Book on Yeri's Achievements as the Military Governor of Edo State published by the 1991.

A Hand Book on the Achievement of Col. Asuquo published by the State Ministry of Information, Benin City, 1993.

A Hand Book, One Year in Office of Group Captain Baba Adamulyam as Military

Administrator of Edo State (August 26, 1996-August 26, 1997) produced by the State Ministry of Information, Benin City, 1996.

A Hand Book titled: His Excellency, Navy Captain Anthony IbeOnyearugbulm Achievements Information, Benin City, 1999.

An Interview with Hon. IgunborEfosa in Benin City, November 20, 2018.

An Interview with IfuekoEghaghe, in Benin City, November 28, 2017

An Interview with Bernard Raji, in Lagos, March 6, 2020.

An Interview with Barrister Charles, Aiyamenkhue, in Benin City, June 8, 2019

An Interview with Hon. Tony Osazuwa, May 6, 2007

Constitution of the Federal Republic of Nigeria, 1979: Section 197.

Col. John EwerekumohYeri's Broadcast to the State, August 30, 1991

Decree 15, 1989, Section 34.

Edo State Environmental Sanitation Edict, 1986.

Ediagbonya, Michael: Military Rule and Development in Nigeria: Edo State as a Case Study Department of History, University of Benin, Benin City, 2007.

The Nigerian Observer, October 16, 1991.

The Nigerian Observer, November 14, 1991.

The Nigerian Observer, January 25, 1995.

The Nigerian Observer, March 9, 1997.

The Nigerian Observers, September 10, 1998.

The Nigerian Observer, October 2, 1998.

The Nigerian Observer, January 25, 1995.

The Nigerian Observer, November 10, 2010.

The Nigerian Observer, February 2, 1994

The Nigerian Observer, February 10, 1994

The Nigerian Observer, January 2, 1995.

Sunday Observer, December 8, 1991.
State Civil Services, University of Benin, M.

State Ministry of Information, Benin City,
(1991-1999). MA Thesis Submitted to the 